OPEN ACCESS

Edited by: Francesca Porri,

South African Institute for Aquatic Biodiversity, South Africa

Reviewed by:

Lauren Sumner-Rooney, University of Oxford, United Kingdom Karen Chan,

Swarthmore College, United States

*Correspondence:

Angela Stevenson

astevenson@geomar.de

Specialty section: This article was submitted to Marine Biology, a section of the journal Frontiers in Marine Science

Received: 26 September 2021 Accepted: 22 December 2021 Published: 13 January 2022

Citation:

Stevenson A, Ó Corcora TC Harley CDG and Baumiller TK (2022) Ability to Swim (Not Morphology or Environment) Explains Interspecific Differences in Crinoid Arm Regrowth.

Front. Mar. Sci. 8:783759. doi: 10.3389/fmars.2021.783759

\section{Ability to Swim (Not Morphology or Environment) Explains Interspecific Differences in Crinoid Arm Regrowth}

\author{
Angela Stevenson ${ }^{1,2,3 *}$, Tadhg C. Ó Corcora ${ }^{1,3}$, Christopher D. G. Harley ${ }^{1,2}$ and \\ Tomasz K. Baumiller ${ }^{4}$ \\ 'Department of Zoology, University of British Columbia, Vancouver, BC, Canada, ${ }^{2}$ Institute for the Oceans and Fisheries, \\ University of British Columbia, Vancouver, BC, Canada, ${ }^{3}$ Marine Evolutionary Ecology, GEOMAR Helmholtz Centre \\ for Ocean Research Kiel, Kiel, Germany, ${ }^{4}$ Museum of Paleontology, Department of Earth and Environmental Sciences, \\ University of Michigan, Ann Arbor, MI, United States
}

Regrowth of body parts occurs in almost every phylum of the animal kingdom, but variation in this process across environmental, morphological, and behavioral gradients remains poorly understood. We examined regeneration patterns in feather stars - a group known for a wide range of morphologies and behaviors and up to a forty-fold difference in arm regeneration rates - and found that the variation in arm regeneration rates is best explained by swimming ability, not temperature, food supply, morphology (total number of arms and number of regenerating arms), or degree of injury. However, there were significant interactive effects of morphology on rates of regeneration of the main effect (swimming ability). Notably, swimmers grew up to three-fold faster than non-swimmers. The temperate feather star Florometra serratissima regenerated faster under warmer scenarios, but its rates fell within that of the tropical species suggesting temperature can account for intraspecific but not interspecific differences. We urge comparative molecular investigations of crinoid regeneration to identify the mechanisms responsible for the observed interspecific differences, and potentially address gaps in stem cell research.

Keywords: behavior, Comatulida, Crinoidea, feather star, mobility, temperate reef, tropical reef, regeneration

\section{INTRODUCTION}

A prominent feature observed among extinct and extant members of class Crinoidea is the presence of regenerating arms (Meyer and Macurda, 1977; Meyer, 1985; Oji and Okamoto, 1994; Oji, 2001; Gahn and Baumiller, 2010). Regeneration is widespread among echinoderms - sea urchins regenerate spines and pedicellaria, sea cucumbers regrow their viscera after evisceration, brittle stars and sea stars regrow arms - but only crinoids possess the extraordinary potential to autotomize and regenerate both external and internal organs ranging from vital organs to limbs (Candia-Carnevali et al., 2009). Crinoid arm regeneration is generally thought to represent the healing of injuries caused by predators, and frequencies of regenerating body parts, such as arms, have been used to gain insights into the intensity of predation (Meyer, 1985; Oji, 1996; Baumiller and Gahn, 2003). Among stalkless crinoids (feather stars, order Comatulida) high regeneration frequencies within a population have been used as evidence of high predation pressure and a multitude of features found among them as anti-predatory defenses. The latter 
include crypticity, nocturnal feeding activity, toxicity, arm number and mobility. Of these, mobility may be the most advantageous as it allows feather stars to crawl, creep, or swim away from predators (Meyer and Macurda, 1977; Oji and Okamoto, 1994; Baumiller et al., 2010). Swimming is thought to have evolved in response to benthic predation (Baumiller et al., 2010; Stevenson et al., 2017), and only eight families of the Comatulida are known to have developed the ability to swim: Atelecrinidae, Antedonidae, Colobometridea, Himerometridae, Mariametridae, Pentametrocrinidae, Thalassometridae, Zygometridae (Utinomi and Kogo, 1965; Fishelson, 1974; La Touche, 1978; Liddell, 1979; Zmarzly, 1984, 1985; Shaw and Fontaine, 1990; Kirkendale and Messing, 2003; Stevens and Connolly, 2003; Kohtsuka and Nakano, 2005; Messing, 2008; Obuchi and Omori, 2015).

In the past two decades, arm regeneration rates in phylogenetically distant and morphologically and behaviorally divergent members of class Crinoidea have been assessed, including Holopodidae (Syverson et al., 2014), Isocrinida (Messing et al., 2007), and three members of the Comatulida (Rhizocrinidae, Veitch and Baumiller, 2021; Antedonidae, Mladenov, 1983; Mariametridae, Baumiller and Stevenson, 2018). A forty-fold difference in rates of arm regeneration has been noted yet factors responsible for this difference remain obscure. Hypothesized controls on echinoderm regeneration rates include food supply, sexual maturity, injury extent, environment, and tissue value. Available evidence suggests that regeneration rates are not strongly influenced by food supply (Clark, 1967; Candia-Carnevali and Bonasoro, 2001) or sexual maturity (Clark, 1967). Although the value of the tissue undergoing regeneration may matter, with parts that are not essential for survival regenerating less rapidly than vital organs (Candia-Carnevali et al., 2009), crinoid arms do not vary in this regard. Extent of injury may be a contributing factor, but supporting evidence is mixed; the feather star Florometra serratissima regenerated slower with increasing number of regenerating arms (Mladenov, 1983), while other studies found faster rates following more extensive arm damage (Perrier, 1873; Reichensperger, 1912). Because deep-water crinoids regenerate much slower than their shallow-water counterparts (Mladenov, 1983; Syverson et al., 2014; Baumiller and Stevenson, 2018; Veitch and Baumiller, 2021), environmental factors such as temperature may contribute to differences observed between species across the bathymetric gradient.

Other factors that may influence regeneration rates relate to dramatic differences in crinoid morphologies and behaviors. Since crinoids are passive suspension feeders capturing food particles with their tubefoot-covered arms (Meyer, 1982), regeneration rates may be related to arm number, which can range from five to several hundred. As arms are used in locomotion, rate of recovery from arm injuries may be under stronger selective pressure for motile than sessile taxa.

To assess the range of interspecific variation in arm regeneration rates, we conducted a four-month, longitudinal field study of tropical feather stars at a single locality (Malatapay, Negros Oriental, Philippines), and a five-month mesocosm experiment on temperate feather star Florometra serratissima. By conducting the field study at a single locality on co-occurring species, the impact of many of the environmental factors could be ignored, allowing us to focus primarily on factors such as morphology (defined herein as total number of arms and number of regenerating arms) and behavior. To cover a broad range of variability of these factors, we selected eight species ranging in average total arm number between 10 and 64 arms, mobility (swimmers vs non-swimmers), and degree of arm injury. The experiments on F. serratissima were designed to assess the effect of elevated temperature on arm regeneration, which the field study did not allow.

\section{MATERIALS AND METHODS}

\section{Laboratory Experiments on Temperate Feather Star Florometra serratissima Collection}

A total of 36 adult Florometra serratissima were randomly selected from Kelvin Grove $(49.449811,-123.240311)$ in Howe Sound, British Columbia, Canada (Figure 1). Individuals were placed in plastic bags with ambient seawater (collected at depth) and stored in coolers for transportation to the laboratory at the University of British Columbia. To ensure longevity, the feather stars were slow drip acclimatized to their tank chemistry over the course of $1 \mathrm{~h}$ by adding $100 \mathrm{~mL}$ of water to the collection bag (stored in a cooler) every $10 \mathrm{~min}$ from the respective tank in which an individual feather star was to be housed. Specimens were never exposed to the air, they were bagged at depth and submerged again in these bags in their mesocosms to reduce touching and air exposure. The feather stars were not weighed because this would require air exposure and extensive manipulations (touching), the combination of both is stressful to the feather star and would result a large number of arms being autotomized. While disc diameter was not measured, only adult individuals were selected for the experiments, and size is not expected to vary between adults. However, because much of the crinoid mass is in their arms, we provide details on species average maximum arm number and maximum arm length for adults (Table 1).

\section{Experimental Set Up}

Individuals were randomly assigned to one of six $250 \mathrm{~L}$ recirculating seawater aquaria (six feather stars per aquarium) bubbled constantly with ambient air and equipped with a multistage filtration system including biological filter (sock filtration, protein skimmer, and bioballs) and UV sterilizer. The feather stars were acclimated in their assigned tanks at $9.8^{\circ} \mathrm{C}$ for four days without food; on the fifth day, the tanks were set to their experimental temperature (control $=9.8^{\circ} \mathrm{C}$; elevated seawater temperature: $+2^{\circ} \mathrm{C}$, maintained at $12^{\circ} \mathrm{C}$ ) over $24 \mathrm{~h}$ and on the sixth day, two arms were amputated from each individual, by pinching an arm and waiting for the feather star to voluntarily release it. Experimental treatments were chosen based on in situ seawater temperature and future climate scenarios (temperature $+2^{\circ} \mathrm{C}$ based on year 2100 projections). Florometra serratissima is exposed to a natural seasonal range of $7-15^{\circ} \mathrm{C}$, 


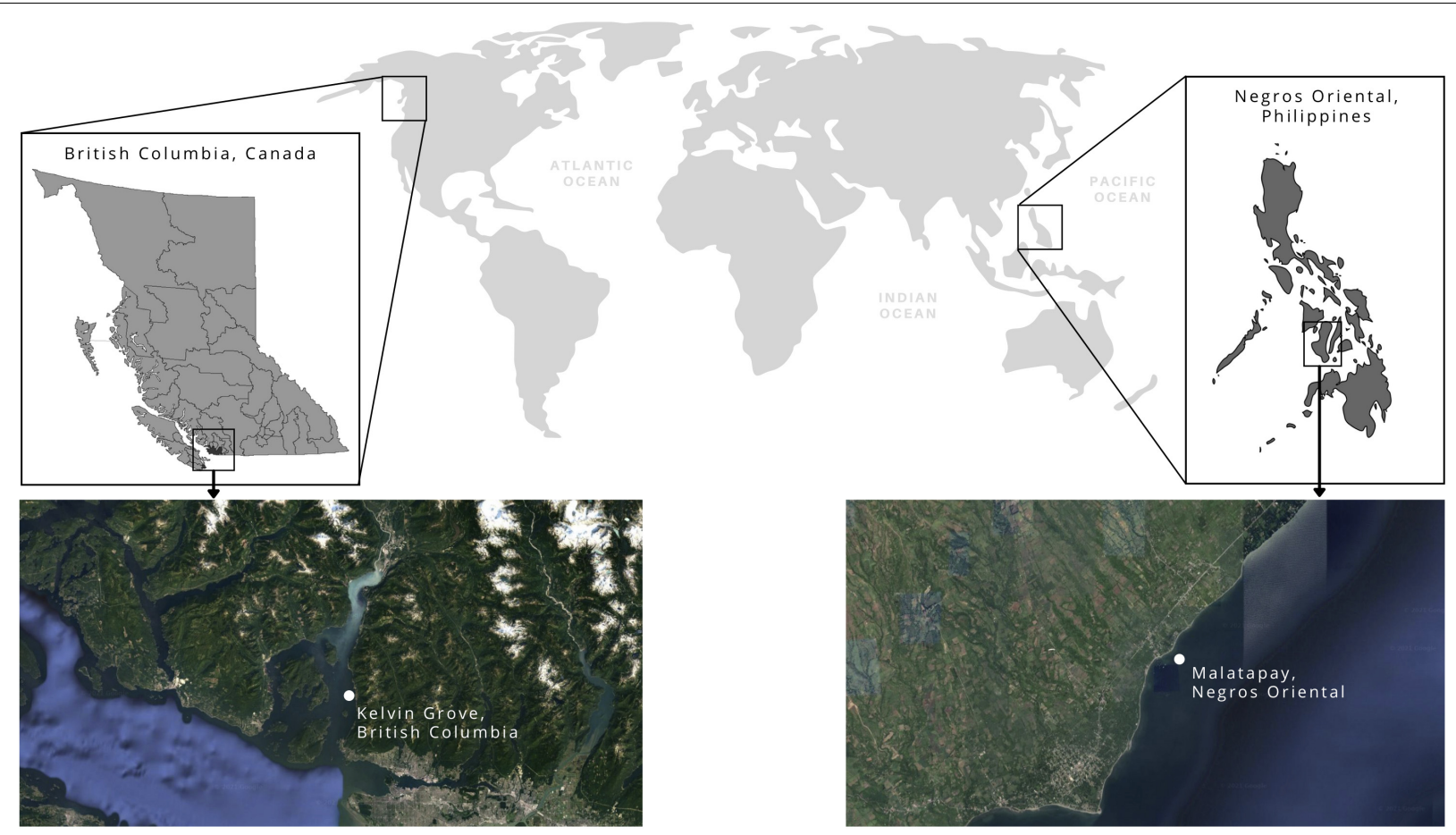

FIGURE 1 | Map of sampling locations in the Pacific Ocean, off the coasts of Kelvin Grove, British Columbia, Canada and Malatapay, Negros Oriental, Philippines. Imagery from Google Earth @ 2021 TerraMetrics Map data (Canada), and @ 2021 CNES/Airbus, Landsat/Copernicus, Maxar Technologies, Map data.

TABLE 1 | Average arm length and arm number for all species examined.

\begin{tabular}{lccc}
\hline Species & Average arm number(count $\mathbf{\pm}$ SD) & Maximum arm length (cm) & References for max. arm length \\
\hline Anneissia bennetti & $62 \pm 9$ & 20 & Messing, 2007 \\
Capillaster multiradiatus & $17 \pm 3$ & 10 & Baumiller and Stevenson, 2018 \\
Clarkcomanthus mirabilis & $40 \pm 5$ & 13 & Baumiller and Stevenson, 2018 \\
Comaster nobilis & $64 \pm 9$ & 13 & Obuchi, 2020 \\
Comatella nigra & $35 \pm 5$ & 9 & Meyer and Macurda, 1980 \\
Florometra serratissima & 10 & 20 & Mladenov, 1983 \\
Oxymetra cf. erinacea & 44 & 10 & Clark, 1941 \\
Phanogenia gracilis & $65 \pm 6$ & 20 & Kirkendale and Messing, 2003 \\
Stephanometra indica & $27 \pm 2$ & 11 & Clark, 1941 \\
\hline
\end{tabular}

Maximum arm length was obtained from the literature. Average arm number was quantified in the field.

as recorded by iButton temperature loggers positioned at the seafloor (23 $\mathrm{m}$ depth) in a nearby location in Howe Sound (see Figure 3 in Stevenson et al., 2020). The two arms were later averaged for regeneration rate calculations and statistical analyses. Feeding began on the eight day. Temperature was measured $4-5 \mathrm{x}$ per week using a combination of YSI (YSI Pro 30) and mercury thermometer, and maintained using individual chillers connected to each tank.

\section{Husbandry}

The source seawater was obtained locally from $16 \mathrm{~m}$ depth in Burrard Inlet, BC, and coarse filtered by the Vancouver Aquarium. The animals were exposed to minimal amounts of light (2-3 h daily) while feeding and photographing regenerating arm lengths. Note: the animals were never exposed to air, even during measurements and initially when transferred from their transport bag to their experimental tanks.

Ammonia, nitrite, nitrate, phosphate, and carbonate hardness (using API Marine Master Test Kit) were monitored throughout the experiment. Seawater $\mathrm{pH}$ was monitored $1-2 \mathrm{x}$ per week using Oakton pH 450 (two-point calibration with saltwater buffers AMP and TRIS, pH 6.77 and 8.09 , respectively, at $25^{\circ} \mathrm{C}$ ). Water changes (20\% of aquaria water) were performed at least once per week, and every two days if high levels of nitrate, or if any traces of ammonia and/or nitrite were present in the tank. The YSI meter was also used to monitor salinity.

The feather stars were fed twice daily (every $12 \mathrm{~h}$ ); each tank received: in the morning, $1 / 8^{\text {th }}$ tsp of Fauna Marine Ultra Min F mixed with $10 \mathrm{~mL}$ seawater; in the evening, $1 / 8^{\text {th }}$ tsp of Fauna Marine Ultra Min Seafan suspended in $10 \mathrm{~mL}$ seawater using a 
Kent Marine Sea Squirt feeder. Four times weekly, the crinoids received $0.5 \mathrm{~mL}$ Fauna Marine Ultra Min S and $0.5 \mathrm{~mL}$ Fauna Marine Ultra Min D mixed with $10 \mathrm{~mL}$ seawater was added to each tank using Kent Marine Sea Squirt feeder. The food was injected up current and near the feather stars, but contact with the animals was avoided during feeding.

\section{Field Experiments on Eight Tropical Feather Star Species}

A total of 123 adult feather stars belonging to eight species were randomly collected during two field campaigns (Dec 2016 - Apr 2017 and Jun - Oct 2018) in Malatapay (9.120909, 123.217840), Negros Oriental, Philippines (Figure 1). All feather stars were hand-collected by closed circuit SCUBA divers from 5 to $35 \mathrm{~m}$ depth. In 2016, individuals were caught, amputated, and released near their original perches (rock, coral, or sponge) at seven locations at $5,10,16,22,25,30,35 \mathrm{~m}$ seawater depth (see summary in Table 2). While we aimed to amputate 3-5 arms per individuals, some autotomized up to ten arms during the process (see summary in Table 3 ). Because these individuals were free to roam between measurements, their perch location was marked to facilitate recapture. In 2018, individuals were caught

TABLE 2 | Summary of feather stars collected during two field campaigns starting in 2016 and 2018, in Malatapay, Negros Oriental, Philippines.

\begin{tabular}{|c|c|c|c|c|c|c|}
\hline \multirow{2}{*}{$\begin{array}{l}\text { Species by start year of } \\
\text { sampling campaign }\end{array}$} & \multicolumn{5}{|c|}{ Sampling depth (m) } & \multirow[t]{2}{*}{ Total } \\
\hline & 5 & 10 & 16 & $22-25$ & $30-35$ & \\
\hline Anneissia bennetti & 11 & 0 & 4 & 3 & 0 & 18 \\
\hline 2016 & 1 & 0 & 0 & 1 & 0 & 2 \\
\hline 2018 & 10 & 0 & 4 & 2 & 0 & 16 \\
\hline Capillaster multiradiatus & 10 & 2 & 8 & 12 & 2 & 34 \\
\hline 2016 & 2 & 2 & 2 & 3 & 2 & 11 \\
\hline 2018 & 8 & 0 & 6 & 9 & 0 & 23 \\
\hline Clarkcomanthus mirabilis & 9 & 1 & 11 & 13 & 1 & 35 \\
\hline 2016 & 2 & 0 & 1 & 2 & 1 & 7 \\
\hline 2018 & 7 & 0 & 10 & 11 & 0 & 28 \\
\hline Comaster nobilis & 0 & 1 & 0 & 1 & 0 & 2 \\
\hline 2016 & 0 & 1 & 0 & 1 & 0 & 2 \\
\hline 2018 & 0 & 0 & 0 & 0 & 0 & 0 \\
\hline Comatella nigra & 4 & 0 & 5 & 7 & 0 & 16 \\
\hline 2016 & 1 & 0 & 0 & 2 & 0 & 3 \\
\hline 2018 & 3 & 0 & 5 & 5 & 0 & 13 \\
\hline Oxymetra cf. erinacea & 0 & 0 & 0 & 1 & 0 & 1 \\
\hline 2016 & 0 & 0 & 0 & 1 & 0 & 1 \\
\hline 2018 & 0 & 0 & 0 & 0 & 0 & 0 \\
\hline Phanogenia gracilis & 0 & 1 & 6 & 4 & 1 & 12 \\
\hline 2016 & 0 & 1 & 4 & 1 & 1 & 7 \\
\hline 2018 & 0 & 0 & 2 & 3 & 0 & 5 \\
\hline Stephanometra indica & 5 & 0 & 0 & 0 & 0 & 5 \\
\hline 2016 & 1 & 0 & 0 & 0 & 0 & 1 \\
\hline \multirow[t]{2}{*}{2018} & 4 & 0 & 0 & 0 & 0 & 4 \\
\hline & & & & & & 123 \\
\hline
\end{tabular}

Species are organized by genus, in alphabetical order. Individuals were free to roam (uncaged) in the 2016 campaign, and caged in the 2018 campaign.
TABLE 3 | Summary of number of regenerating arms in feather stars examined during the field campaigns in Malatapay, Negros Oriental, Philippines, distributed across depth.

\begin{tabular}{|c|c|c|c|c|c|c|}
\hline \multirow{2}{*}{$\begin{array}{l}\text { Number of regenerating } \\
\text { arms per individual }\end{array}$} & \multicolumn{5}{|c|}{ Sampling depth (m) } & \multirow[t]{2}{*}{ Total } \\
\hline & 5 & 10 & 16 & $22-25$ & $30-35$ & \\
\hline \multicolumn{7}{|l|}{ Anneissia bennetti } \\
\hline 3 & 1 & 0 & 0 & 0 & 0 & 1 \\
\hline 4 & 5 & 0 & 2 & 1 & 0 & 8 \\
\hline 5 & 2 & 0 & 1 & 1 & 0 & 4 \\
\hline 6 & 2 & 0 & 1 & 0 & 0 & 3 \\
\hline 9 & 0 & 0 & 0 & 1 & 0 & 1 \\
\hline 11 & 1 & 0 & 0 & 0 & 0 & 1 \\
\hline \multicolumn{7}{|l|}{ Capillaster multiradiatus } \\
\hline 3 & 0 & 1 & 1 & 0 & 0 & 2 \\
\hline 4 & 7 & 1 & 4 & 7 & 1 & 20 \\
\hline 5 & 2 & 0 & 0 & 2 & 1 & 5 \\
\hline 6 & 1 & 0 & 3 & 3 & 0 & 7 \\
\hline \multicolumn{7}{|l|}{ Clarkcomanthus mirabilis } \\
\hline 3 & 1 & 0 & 0 & 0 & 0 & 1 \\
\hline 4 & 2 & 1 & 7 & 5 & 1 & 16 \\
\hline 5 & 1 & 0 & 0 & 1 & 0 & 2 \\
\hline 6 & 2 & 0 & 3 & 4 & 0 & 9 \\
\hline 7 & 0 & 0 & 0 & 1 & 0 & 1 \\
\hline 8 & 1 & 0 & 1 & 1 & 0 & 3 \\
\hline 9 & 0 & 0 & 0 & 1 & 0 & 1 \\
\hline 10 & 2 & 0 & 0 & 0 & 0 & 2 \\
\hline \multicolumn{7}{|l|}{ Comaster nobilis } \\
\hline 4 & 0 & 1 & 0 & 1 & 0 & 2 \\
\hline \multicolumn{7}{|l|}{ Comatella nigra } \\
\hline 2 & 0 & 0 & 1 & 0 & 0 & 1 \\
\hline 3 & 1 & 0 & 0 & 1 & 0 & 2 \\
\hline 4 & 3 & 0 & 4 & 6 & 0 & 13 \\
\hline \multicolumn{7}{|l|}{ Oxymetra cf. erinacea } \\
\hline 3 & 0 & 0 & 0 & 1 & 0 & 1 \\
\hline \multicolumn{7}{|l|}{ Phanogenia gracilis } \\
\hline 4 & 0 & 0 & 2 & 4 & 0 & 6 \\
\hline 5 & 0 & 1 & 1 & 0 & 0 & 2 \\
\hline 6 & 0 & 0 & 1 & 0 & 0 & 1 \\
\hline 8 & 0 & 0 & 1 & 0 & 0 & 1 \\
\hline 10 & 0 & 0 & 1 & 0 & 0 & 1 \\
\hline 11 & 0 & 0 & 0 & 0 & 1 & 1 \\
\hline \multicolumn{7}{|l|}{ Stephanometra indica } \\
\hline 3 & 1 & 0 & 0 & 0 & 0 & 1 \\
\hline 4 & 2 & 0 & 0 & 0 & 0 & 2 \\
\hline 5 & 1 & 0 & 0 & 0 & 0 & 1 \\
\hline 6 & 1 & 0 & 0 & 0 & 0 & 1 \\
\hline
\end{tabular}

Species are organized by genus, in alphabetical order.

and placed in identical cages $(1.0 \times 1.0 \times 0.5 \mathrm{~m})$ stationed at 5, 16, and $25 \mathrm{~m}$ depth (see summary in Table 2). Each cage consisted of a bamboo frame with mesh material on all sides of the cage, effectively sealing the individuals in the cage. Cage dimensions gave individuals sufficient space to move about the cage without coming in contact with each other and for the longest of the crinoid arms to fully extend during feeding. Mesh 
pore size ( $3 \mathrm{~mm}$ diameter) allowed for water to flow through the cage, bringing tiny food particles to the feather stars within.

\section{Analyses}

\section{Measurement of Regenerating Arms}

In all instances, multiple (lab $N=2$, field $N=3-7$ ) adjacent arms were amputated in a fixed pattern (approximately the same proximal syzygy) by pinching the arm and waiting for the feather star to voluntarily release it. The oral and aboral sides of each individual were photographed to facilitate identification. Regenerating arms were photographed alongside a scale bar roughly once every 20 days for 170 (lab) or 124 (field) days. Regenerating arm lengths were calculated using the 'segments' function in Image version 1.47 (Schneider et al., 2012). Measurements excluded the arm stump.

\section{Statistical Analyses}

All statistical analyses were performed in $\mathrm{R}$ version 3.6.2 ( $\mathrm{R}$ Core Team, 2019) for Mac OS X. For all tests, significance was determined at $p<0.05$. Data were square-root transformed to meet the assumptions of normality and equal variance. All mixed models were performed with package "nlme" (Pinheiro et al., 2019). Visual inspection of standard model validation graphs was used to verify model assumptions: residuals versus fitted values were used to verify homogeneity; a histogram or QuantileQuantile ( $\mathrm{q}-\mathrm{q}$ ) plot of the residuals for normality; and residuals versus each explanatory variable to check independence. Fixed and random predictor variables lacking explanatory power were eliminated via AIC model selection (Zuur et al., 2009). Optimal model structures were obtained first for random effects and next for fixed effects. To account for repeated measures on individuals through time, an autoregressive (AR1) correlation structure was included in all linear models during the selection process. In all cases, the most parsimonious model was selected (i.e., the one without interactions and/or fewer terms, least complex random structure, and removal of correlation structure where necessary). Linear mixed models (LMM) fit by maximum likelihood were used to examine the effect of warming ( $F$. serratissima only); and total arm number, number of arms regenerating, and ability to swim (Philippine species only) on arm regeneration rate. The two best models included a random intercept in which variation around that intercept depended on the feather star nested within the tank ( $F$. serratissima) and nested by depth (Philippine species). Depth was included in the model as a random effect so as to account for the spatial autocorrelation between individuals at each depth, and it was also included in the correlation structure because we conducted repeated measures on the same individuals over time, at different depths. Because a different method was used in 2016 (caged) and 2018 (not caged), sampling year was initially included in the model to test the impact of the method change, but it (and its interaction) did not have a significant effect or contribute to the model so it was removed from the final model.

\section{RESULTS}

\section{Rates of Regeneration in Swimming Temperate Feather Star Florometra serratissima}

Over the course of the laboratory experiment, F. serratissima exposed to warming regenerated significantly faster (by $0.1 \mathrm{~mm} /$ day) than control individuals exposed to ambient conditions (Figure 2 and Table 4).

\section{Rates of Regeneration in Eight Tropical Feather Stars}

The range of arm regeneration rates among feather stars of Malatapay, Philippines, was broad, between 0.29 and $1.01 \mathrm{~mm} /$ day (Figure 3). Of the non-swimming feather

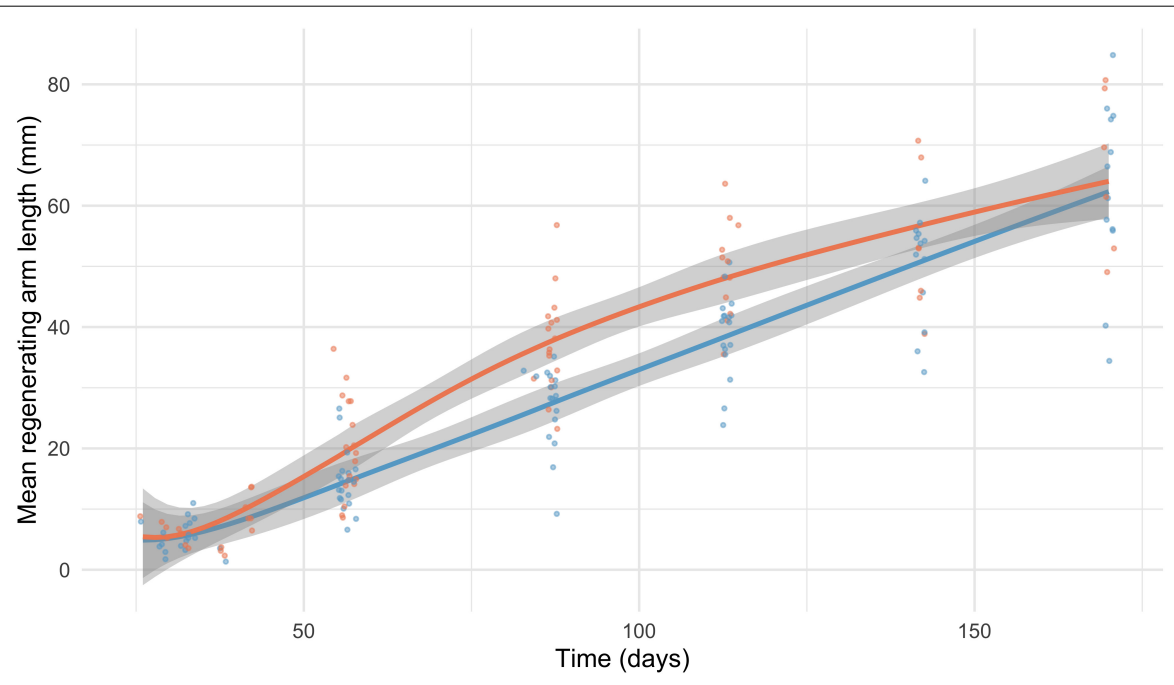

FIGURE 2 | Regenerating arm length over time of temperate swimming feather star, Florometra serratissima, exposed to ambient (blue, $\left.9.8^{\circ} \mathrm{C}\right)$ and warm (red, $\left.12^{\circ} \mathrm{C}\right)$ treatments in the lab. The $95 \%$ confidence interval of each curve is shown. 
TABLE 4 | Results of the optimal, most parsimonious Linear Mixed Model testing for independent and interactive effects of warming (Florometra serratissima only), total arm number and ability to swim (Philippine species only) on crinoid arm regeneration.

\begin{tabular}{|c|c|c|c|c|c|}
\hline Source of error & Estimate & Std. Error & DF & t-value & $p$-value \\
\hline \multicolumn{6}{|l|}{ Florometra serratissima arm regeneration rates (LMM) } \\
\hline Intercept & 0.3913 & 0.0270 & 131 & 14.4870 & $<0.0001$ \\
\hline Warmer & 0.1098 & 0.0407 & 4 & 2.6959 & 0.05 \\
\hline \multicolumn{6}{|c|}{ Philippine taxa arm regeneration rates (LMM, square-root transformed, corAR1) } \\
\hline Intercept & 0.7303 & 0.0885 & 406 & 8.2476 & $<0.0001$ \\
\hline Total arm number & -0.0008 & 0.0019 & 107 & -0.4167 & 0.7 \\
\hline Swim (yes) & 3.8746 & 1.7526 & 107 & 2.2108 & 0.03 \\
\hline Total arms regenerating & 0.0136 & 0.0187 & 107 & 0.7279 & 0.5 \\
\hline Total arm number $\times$ Swim (yes) & -0.1631 & 0.0701 & 107 & -2.3255 & 0.02 \\
\hline Total arm number $\times$ Total arms regenerating & -0.0003 & 0.0004 & 107 & -0.6631 & 0.5 \\
\hline Swim (yes) $\times$ Total arms regenerating & -1.3534 & 0.5934 & 107 & -2.2807 & 0.02 \\
\hline Total arm regenerating $\times$ Swim (yes) $\times$ Total arms regenerating & 0.0571 & 0.0235 & 107 & 2.4286 & 0.02 \\
\hline
\end{tabular}

Statistically significant effects in bold, alpha $=0.05$.

stars, Comaster nobilis regenerated slowest and Comatella nigra regenerated fastest. Swimming feather stars of family Mariametridae (S. indica, O. cf. erinacea) regenerated at a rate of $0.89-1.01 \mathrm{~mm} / \mathrm{day}$, significantly faster (by 1.4 to 3.5 times) than the six non-swimming feather stars of family Comatulidae (A. bennetti, C. multiradiatus, $C$ mirabilis, $C$. nobilis, $C$. nigra, $P$. gracilis) (Figure 3 and Table 4). While arm regeneration rate decreased with increasing total arm number and increased slightly with total number of regenerating arms, statistically these two factors alone do not account for the differences observed between species (Table 4). However, the interactive effect of total arm number and total regenerating arm number on rates of regeneration was smaller (by -0.158 and -1.310 , respectively) in swimmers compared to non-swimming feather stars when considered individually (two-way interaction, Table 4), but together (three-way interaction, Table 4) the effect on arm regeneration rate was increased in swimmers (0.057). All interactive effects with swimming ability were significant.

\section{DISCUSSION}

Our results suggest large interspecific differences in rates of regeneration $(0.29$ to $1.01 \mathrm{~mm} /$ day $)$ in eight feather stars from a near-shore community of Malatapay, Philippines. Of the parameters studied here, swimming ability alone (not environment or morphology) was found to be the best explanation for these interspecific differences. Swimming ability in feather stars has been hypothesized as an adaptation used to escape non-lethal encounters with benthic predators (Baumiller et al., 2010). It is possible that swimming efficiency may be compromised by missing limbs and so rapid regeneration of arms may be paramount to the survival of feather stars that use this behavior to escape predators.

In the context of the above results from Malatapay, the effect of temperature on $F$. serratissima regeneration rates is intriguing. Florometra serratissima regenerated arms significantly faster at the warmer temperature: $0.4 \mathrm{~mm} / \mathrm{d}$ at $9.8^{\circ} \mathrm{C}$ and $0.5 \mathrm{~mm} / \mathrm{d}$ at $12^{\circ} \mathrm{C}$. This was as expected because metabolic rates decline strongly with decreasing temperature (Gillooly et al., 2001; Brown et al., 2004). Unexpectedly, F. serratissima rates fell within the range of tropical feather stars in spite of a $17^{\circ} \mathrm{C}$ temperature difference between the two locations. Using the metabolic theory of ecology (MTE) to correct for temperature (Brown et al., 2004), the Boltzmann-Arrhenius relationship was used to estimate how regeneration rates might vary at the predicted thermal optima of $19^{\circ} \mathrm{C}$ in temperate invertebrates (Dell et al., 2011), like F. serratissima, versus $12^{\circ} \mathrm{C}$ and $9.8^{\circ} \mathrm{C}$ waters (Eq. 1).

$$
\text { Rrate } \sim \mathrm{e}^{-(\mathrm{E} / \mathrm{kT})}
$$

where $\mathrm{E}$ is the activation energy $(\sim 0.65 \mathrm{eV}), \mathrm{k}$ is Boltzmann's constant $\left(8.62 \times 10^{-5} \mathrm{eV} / \mathrm{K}\right)$ and $\mathrm{T}$ is temperature in Kelvin.

Corrected F. serratissima rates fell above the range of nonswimming tropical feather stars regenerating at $29^{\circ} \mathrm{C}$ (the temperature measured at our site in Malatapay), and were similar to that of the two swimming species. The MTE-predicted arm regeneration rate at $19^{\circ} \mathrm{C}$ is expected to be 2.315 times the rate at $9.8^{\circ} \mathrm{C}$ and 1.885 times that at $12^{\circ} \mathrm{C}$. For F. seratissima at $19^{\circ} \mathrm{C}$, that would mean MTE-predicted values between 0.93 and $0.94 \mathrm{~mm} /$ day.

It must be noted that the high rates of growth observed in swimming tropical taxa are fully confounded with family because the swimming and non-swimming taxa examined here belong to two distinct families - Mariametridae and Comatulidae, respectively - making it difficult to separate the effects of swimming ability and family. However, F. serratissima belongs to swimming family Antedonidae. MTE corrected growth rates of F. serratissima, suggest that swimming ability, not family, confer rapid regeneration thus supporting the proposed swimming hypothesis. However, it must be noted that the BoltzmannArrhenius relationship does not consider other factors that can interact with arm regeneration such as total arm number and total regenerating arm number.

It may be that swimming feather stars regenerate as fast as they can and the lower rate observed in $F$. serratissima is a consequence of environmental constraint (in this case, 
A

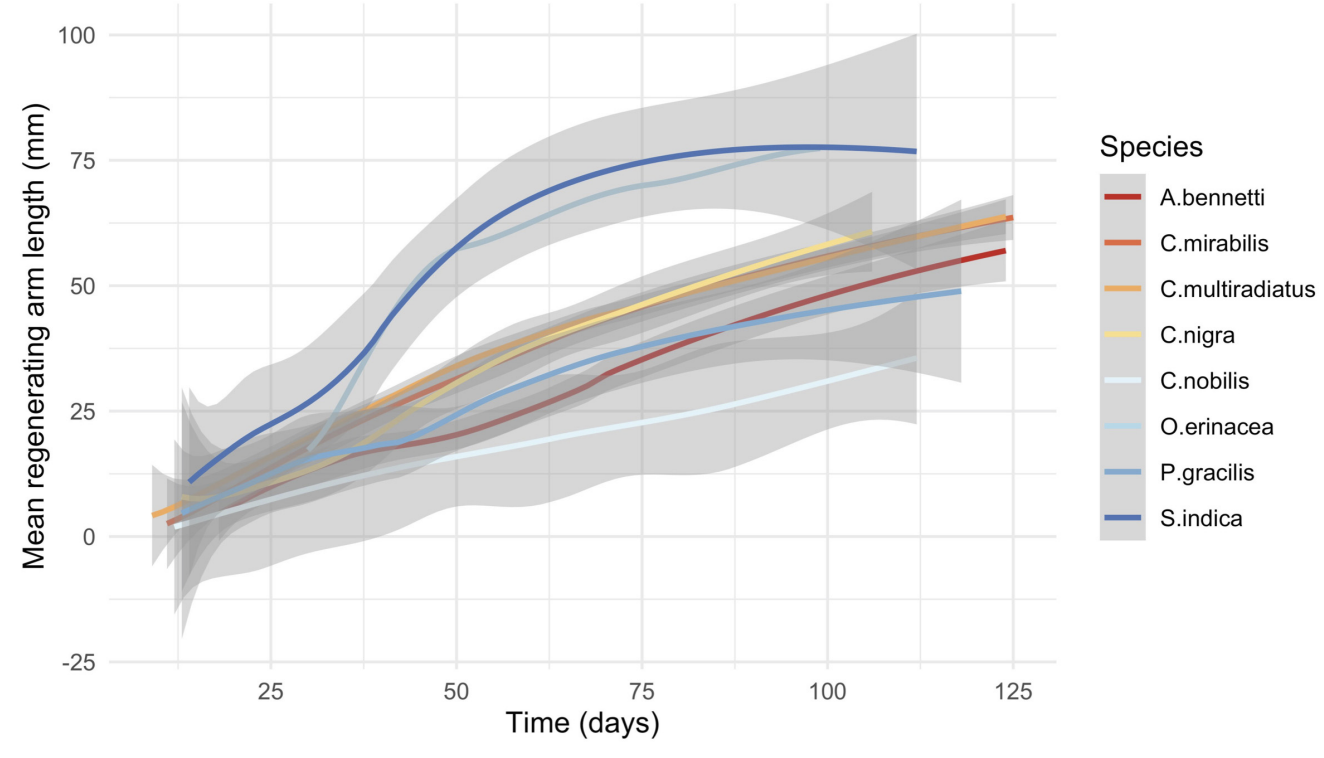

B

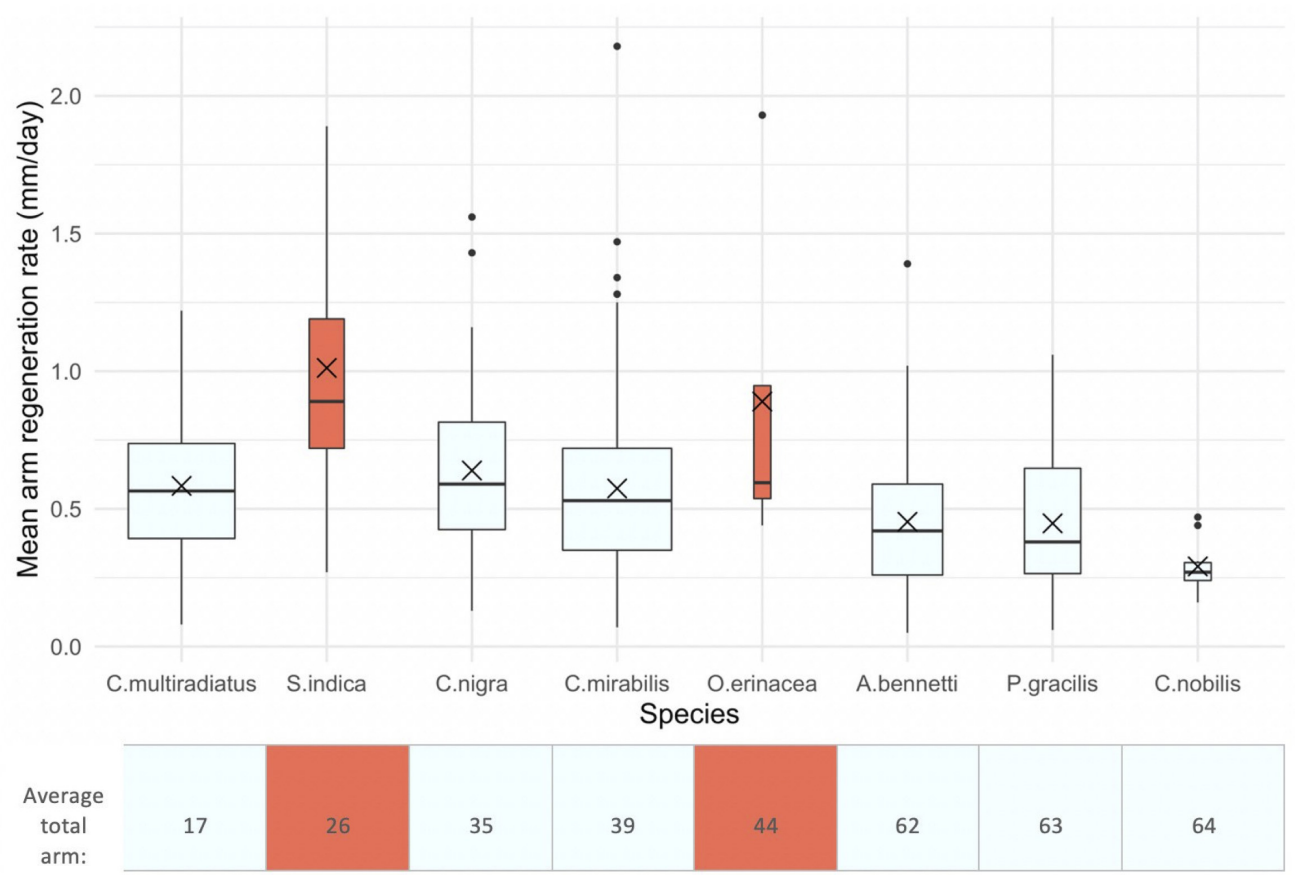

FIGURE 3 | Arm length over time (A) and mean regeneration rates of eight tropical feather stars (B): six non-swimming [blue in (B)] family Comatulidae (Anneissia bennetti, Capillaster multiradiatus, Clarkcomanthus mirabilis, Comaster nobilis, Comatella nigra, Phanogenia gracilis), and two swimming [red in (B)] family Mariametridae (Oxymetra cf. erinacea, Stephanometra indica). (A) The 95\% confidence interval of each curve is shown. (B) Species are ordered by average arm number, increasing from left to right. Box and whiskers show the median as a line, first and third quartiles as hinges, and the highest and lowest values within 1.5 times the inter-quartile range as whiskers. $X=$ mean. Generated from 535 independent segments on 123 adult feather stars. Boxplot width scaled with sample size.

colder temperatures). It is also important to note that biological processes are slower at colder temperatures (Gillooly et al., 2001; Brown et al., 2004), including the activity of their coldblooded predators (like fish and sea urchins in the Philippines, Stevenson and Baumiller, 2020; sea star Pycnopodia helianthoides and crab Oregonia gracilis in British Columbia, Mladenov, 1983). While temperature could explain the intraspecific difference in arm regeneration rates of $F$. serratissima, it is not clear if these could explain differences observed between F. serratissima and the tropical taxa. 


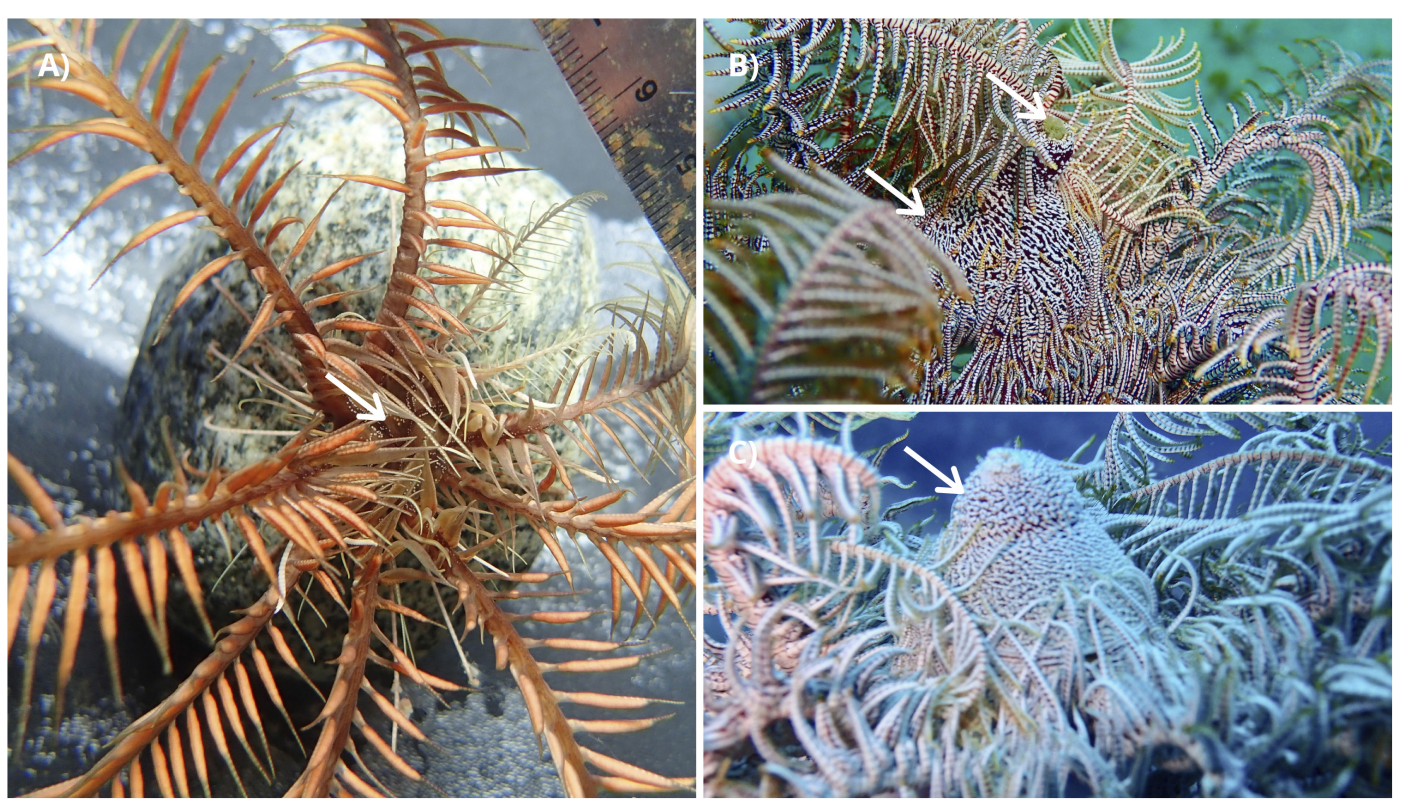

FIGURE 4 | Stomach of Florometra serratissima in the lab (A), and two individuals of Clarkcomanthus mirabilis in the field (B,C). Note the bulging stomachs of C. mirabilis, with feces protruding [(B), top arrow] versus the absence of this in F. serratissima (A). Arrows point to the stomach of each individual.

Arm regeneration rates of $F$. serratissima in the present study $(0.4-0.5 \pm 0.1 \mathrm{~mm} /$ day $)$ are consistent with those previously reported by Mladenov (1983), who examined F. serratissima in the field $(0.4-0.6 \mathrm{~mm} /$ day $)$. In the lab, nutrient load was optimized to meet the nutritional needs of $F$. serratissima while also minimizing food build up and nitrification to maximize water quality in our recirculating mesocosm system. For this reason, individuals kept in captivity were not fed continuously, but rather twice daily, and their stomachs were never seen bulging full of food (Figure 4A) - a phenomenon seen in natural feather star populations (Figures 4B,C). In contrast, individuals examined by Mladenov (1983) under natural conditions in the field, likely received an unlimited and continuous supply of food. Similar rates of regeneration under vastly different food scenarios (food-constrained lab scenario versus the unconstrained field scenario) suggest that food supply, and thus feeding ability (e.g., via increased arm number), does not impact arm regeneration rates in F. serratissima. This is consistent with observations from the monograph of existing crinoids (Clark, 1967) and the inability of morphology (total arm number) alone to explain the observed variation between Malatapay species.

Contradictory results have previously been reported for the effect of regenerating arm number on regeneration rates (e.g., Perrier, 1873 vs. Mladenov, 1983; Reichensperger, 1912). Mladenov (1983) reported a slower rate with increasing number in F. serratissima while others found faster rates following extensive arm damage (e.g., more regenerating arms) (Perrier, 1873; Reichensperger, 1912). Our results suggest that the effect of the degree of injury on rates of regeneration is indeed complex. The number of regenerating arms alone could not explain the observed differences in regeneration rates between Malatapay species, but it had a greater effect on non-swimming feather stars than swimming ones. And when considered with total number of arms, the degree of injury had a greater effect on swimming than non-swimming feather stars.

\section{Implications for Comparative and Evolutionary Biology}

Although our results show that feather stars capable of swimming regenerate their arms faster than those that can only crawl, our observations and experiments offer no insights into the molecular mechanisms that might be involved. Perhaps greater insights into such mechanisms might be gained by comparing feather stars, all of which either crawl, swim or do both, to a closely related, derived group of comatulids that can neither crawl nor swim: the rhizocrinoids. A crucial difference between feather stars and rhizocrinids lies in their development. Juvenile feather stars spend the first $45-60$ days fused to the seafloor by a stalk (Grimmer et al., 1984; Kohtsuka and Nakano, 2005; Shibata et al., 2008), and become free living once the stalk is shed, giving their adult form the advantage of mobility to escape predators. The rhizocrinids, somewhere in their evolutionary history lost the ability to shed their stalk, and live their entire life with a stalk anchoring them to the seafloor, with crown autotomy and regeneration as their antipredator defensive mechanisms (Veitch and Baumiller, 2021). There is only one study that examined arm regeneration rates in these fully sessile, pedomorphic rhizocrinids and that study reports a rate slower than that found among any feather stars (Veitch and Baumiller, 2021). While this needs to be investigated further, it suggests that regeneration rates vary along a gradient from sessile through crawling to swimming. For example, could a change in rates be associated with the ontogenetic event of 
stalk shedding, in which case juvenile feather stars should be characterized by low rates and rhizocrinids would have retained the rate through pedomorphosis? We do not currently know much about the metabolic rates or feeding rates in swimming vs. non-swimming species. Swimming species, being more active, could have higher rates of either/both, which could help explain their apparent ability to regenerate faster. However, it is clear that comatulids with their widely varying rates provide a rich and interesting system for comparative studies of regeneration that could integrate behavioral, morphological, developmental approaches with stem cell research.

\section{DATA AVAILABILITY STATEMENT}

The raw data supporting the conclusions of this article will be made available by the authors, without undue reservation.

\section{AUTHOR CONTRIBUTIONS}

AS and TB: conceptualization. AS, TÓC, and TB: methodology. AS and TÓC: data acquisition and analyses. AS: writing original draft. $\mathrm{CH}$ and TB: supervision. AS, $\mathrm{CH}$, and TB: funding

\section{REFERENCES}

Baumiller, T. K., and Gahn, F. J. (2003). "Chapter 10, Predation on crinoids," in Predator-Prey Interactions in the Fossil Record, Topics in Geobiology, Vol. 20, eds P. Kelley, M. Kowalewski, and T. H. Hansen (New York, NY: Kluwer Academic), 263-278. doi: 10.1007/978-1-4615-0161-9_11

Baumiller, T. K., and Stevenson, A. (2018). Reconstructing predation intensity on crinoids using longitudinal and cross-sectional approaches. Swiss J. Palaeontol. 137, 189-196.

Baumiller, T. K., Salamon, M. A., Gorzelak, P., Mooi, R., Messing, C. G., and Gahn, F. J. (2010). Post-Paleozoic crinoid radiation in response to benthic predation preceded the Mesozoic marine revolution. Proc. Natl. Acad. Sci. U.S.A. 107, 5893-5896. doi: 10.1073/pnas.0914199107

Brown, J. H., Gillooly, J. F., Allen, A. P., Savage, V. M., and West, G. B. (2004). Toward a metabolic theory of ecology. Ecology 85, 1771-1789.

Candia-Carnevali, M. D., and Bonasoro, F. (2001). Introduction to the biology of regeneration in echinoderms. Microsc. Res. Tech. 55, 365-368. doi: 10.1002/ jemt.1184

Candia-Carnevali, M. D., Thorndyke, M. C., and Matranga, V. (2009). "Regenerating echinoderms: a promise to understand stem cells potential," in Stem cells in Marine Organisms, eds B. Rinkevich and V. Matranga (Dordrecht: Springer), 165-186. doi: 10.1007/978-90-481-2767-2_7

Clark, A. H. (1941). A Monograph of the Existing Crinoids: The Comatulids, Vol. 1. Washington, D.C: Smithsonian Institution.

Clark, A. H. (1967). A Monograph of the Existing Crinoids: by Austin Hobart Clark, Vol. 1. Washington, DC: US Government Printing Office.

Dell, A. I., Pawar, S., and Savage, V. M. (2011). Systematic variation in the temperature dependence of physiological and ecological traits. Proce. Natl. Acad. Sci. U.S.A. 108, 10591-10596. doi: 10.1073/pnas.1015178108

Fishelson, L. (1974). Ecology of the northern Red Sea crinoids and their epi- and endozoic fauna. Mar. Biol. 26, 183-192. doi: 10.1007/bf00388888

Gahn, F. J., and Baumiller, T. K. (2010). Evolutionary history of regeneration in crinoids (Echinodermata). Integr. Comp. Biol. 50, 514a-514m. doi: 10.1093/icb/ icq155

Gillooly, J. F., Brown, J. H., West, G. B., Savage, V. M., and Charnov, E. L. (2001). Effects of size and temperature on metabolic rate. Science 293, 2248-2251. acquisition. All authors contributed intellectual input, edited and approved this manuscript.

\section{FUNDING}

This work was supported by the NSERC CREATE Training Our Future Ocean Leaders Program Postdoctoral Fellowship, the Percy Sladen Memorial Fund, and Challenger Society for Marine Sciences Stepping Stone Bursary to AS, and a Natural Sciences and Engineering Research Council Discovery Grant and Canada Foundation for Innovation grant to $\mathrm{CH}$.

\section{ACKNOWLEDGMENTS}

Many thanks are due to Carli Jones, Charlotte Matthews, Colin MacLeod, Emma Foxcroft, Robert Hechler, Madison Kaplan, Maya Brassard, Mikalyn Trinca Colonel in the lab; Cassandra Konecny, Chase Byerly, Jenn Burt, Jillian Campbell, John Cristiani, Lauran Liggan, Marine Conservation Philippines, Margaret Veitch, Raffy Casinares, Søren Knudsen, Victoria Burdett-Coutts in the field. Forest Gahn for advice with crinoid husbandry, and Chuck Messing for his help with species identification.

Grimmer, J. C., Holland, N. D., and Kubota, H. (1984). The fine structure of the stalk of the pentacrinoid larva of a feather star, Comanthus japonica (Echinodermata: Crinoidea). Acta Zool. 65, 41-58. doi: 10.1111/j.1463-6395. 1984.tb00808.x

Kirkendale, L., and Messing, C. G. (2003). An annotated checklist and key to the Crinoidea of Guam and the Commonwealth of the Northern Marianas Islands. Micronesica 35, 523-546.

Kohtsuka, H., and Nakano, H. (2005). Development and growth of the feather star Decametra igrine (Crinoidea), with emphasis on the morphological differences between adults and juveniles. J. Mar. Biol. Assoc. U. K. 85, 1503. doi: 10.1017/ s0025315405012701

La Touche, R. W. (1978). The feeding behaviour of the featherstar Antedon bifida (Echinodermata: Crinoidea). J. Mar. Biol. Assoc. U. K. 58, 877-890.

Liddell, W. D. (1979). Shallow-water comatulid crinoids (Echinodermata) from Barbados, West Indies. Can. J. Zool. 57, 2413-2420. doi: 10.1139/z79-313

Messing, C. G. (2007). The crinoid fauna (Echinodermata: Crinoidea) of Palau. Pac. Sci. 61, 91-111. doi: 10.1353/psc.2007.0010

Messing, C. G. (2008). A new species of five-armed feather star, Pentametrocrinus paucispinulus n. sp., from the eastern Pacific (Echinodermata: Crinoidea: Comatulida). Proc. Biol. Soc. Washington 121, 269-275.

Messing, C. G., David, J., Roux, M., Ameiziane, N., and Baumiller, T. K. (2007). In situ stalk growth rates in tropical western Atlantic sea lilies (Echinodermata: Crinoidea). J. Exp. Mar. Biol. Ecol. 353, 211-220. doi: 10.1016/j.jembe.2007.08. 021

Meyer, D. L. (1982). "Food composition and feeding behavior of sympatric species of comatulid crinoids from the Palau Islands (Western Pacific)," in Proceedings of the International Conference, Tampa Bay, ed. J. M. Lawrence (Rotterdam: A. A. Balkema), 43-49. doi: 10.18353/crustacea.37.0_43

Meyer, D. L. (1985). Evolutionary implications of predation on recent comatulid crinoids from the Great Barrier Reef. Paleobiology 11, 154-164. doi: 10.1017/ S0094837300011477

Meyer, D. L., and Macurda, D. B. Jr. (1977). Adaptive radiation of the comatulid crinoids. Paleobiology 3, 74-82. doi: 10.1017/s0094837300005121

Meyer, D. L., and Macurda, D. B. Jr. (1980). Ecology and distribution of the shallow-water crinoids of Palau and Guam. Micronesica 16, 59-99. 
Mladenov, P. V. (1983). Rate of arm regeneration and potential causes of arm loss in the feather star Florometra serratissima (Echinodermata: Crinoidea). Can. J. Zool. 61, 2873-2879.

Obuchi, M. (2020). Shallow-water Comatulids (Echinodermata: Crinoidea: Comatulida) of the Ashizuri-Uwakai Sea, Shikoku Island, Southern Japan. Species Divers. 25, 309-328. doi: 10.12782/specdiv.25.309

Obuchi, M., and Omori, A. (2015). A new genus and new species of family Antedonidae (Echinodermata: Crinoidea) from southern Japan. Zootaxa 3972, 441-449. doi: 10.11646/zootaxa.3972.3.9

Oji, T. (1996). Is predation intensity reduced with increasing depth? Evidence from the west Atlantic stalked crinoid Endoxocrinus parrea (Gervais) and implications for the Mesozoic marine revolution. Paleobiology 22, 339-351. doi: $10.1017 / \mathrm{s} 0094837300016328$

Oji, T. (2001). Fossil record of echinoderm regeneration with special regard to crinoids. Microsc. Res. Tech. 55, 397-402. doi: 10.1002/jemt.1186

Oji, T., and Okamoto, T. (1994). Arm autotomy and arm branching pattern as antipredatory adaptations in stalked and stalkless crinoids. Paleobiology 20, 27-39. doi: $10.1017 /$ s0094837300011118

Perrier, E. (1873). Recherches sur l'anatomie et le régénération des bras de la Comatula rosacea (Antedon rosaceus, Linck). Arch. Zool. Exp. Gen. 2, 29-86.

Pinheiro, J., Bates, D., DebRoy, S., Sarkar, D., and R Core Team (2019). Nlme: Linear and Nonlinear Mixed Effects Models. R Package Version 3.1-139. Available online at: https://CRAN.R-project.org/package=nlme (accessed September 07, 2021).

R Core Team (2019). R: A Language and Environment for Statistical Computing. Vienna: R Foundation for Statistical Computing.

Reichensperger, A. (1912). Beitrage zur histologie und zum verlauf der regeneration bei crinoiden. Z. Wiss. Zool. 101, 1-69.

Schneider, A., Rasband, W. S., and Eliceiri, K. W. (2012). "NIH Image to ImageJ: 25 years of image analysis. Nat. Methods 9, 671-675. doi: 10.1038/nmeth.2089

Shaw, G. D., and Fontaine, A. R. (1990). The locomotion of the comatulid Florometra serratissima (Echinodermata: Crinoidea) and its adaptive significance. Can. J. Zool. 68, 942-950.

Shibata, T. F., Sato, A., Oji, T., and Akasaka, K. (2008). Development and growth of the feather star Oxycomanthus japonicus to sexual maturity. Zool. Sci. 25, 1075-1083. doi: 10.2108/zsj.25.1075

Stevens, T., and Connolly, R. M. (2003). Shallow-water crinoids are on soft sediments too: evidence from a video survey of a subtropical estuary. Bull. Mar. Sci. 73, 593-604.

Stevenson, A., and Baumiller, T. K. (2020). Threadfin hawkfish predation on stalkless crinoid. Front. Ecol. Environ. 18:485. doi: 10.1002/fee.2272

Stevenson, A., Archer, S. K., Schultz, J. A., Dunham, A., Marliave, J. B., Martone, P., et al. (2020). Warming and acidification threaten glass sponge Aphrocallistes vastus pumping and reef formation. Sci. Rep. 10:8176. doi: 10.1038/s41598-02065220-9

Stevenson, A., Gahn, F. J., Baumiller, T. K., and Sevastopulo, G. D. (2017). Predation on feather stars by regular echinoids as evidenced by laboratory and field observations and its paleobiological implications. Paleobiology 43, 274-285. doi: 10.1017/pab.2016.39

Syverson, V. J., Messing, C. G., Stanley, K., and Baumiller, T. K. (2014). Growth, injury, and population dynamics in the extant cyrtocrinid Holopus mikihe (Crinoidea, Echinodermata) near Roatán, Honduras. Bull. Mar. Sci. 91, 47-61. doi: $10.5343 /$ bms.2014.1061

Utinomi, H., and Kogo, I. (1965). On some comatulids from the coastal sea of Kii Peninsula. Public. Seto Mar. Biol. Lab. 13, 263-286.

Veitch, M. A., and Baumiller, T. K. (2021). Low predation intensity on the stalked crinoid Democrinus sp. (Echinodermata), in Roatán, Honduras, reveals deep water as likely predation refuge. Bull. Mar. Sci. 97, 107-128.

Zmarzly, D. L. (1984). Distribution and ecology of shallow-water crinoids at Enewetak Atoll, Marshall Islands, with an annotated checklist of their symbionts. Pac. Sci. 38, 105-122.

Zmarzly, D. L. (1985). The shallow-water crinoid fauna of Kwajalein Atoll, Marshall Islands: ecological observations, interatoll comparisons, and zoogeographic affinities. Pac. Sci. 39, 340-358.

Zuur, A., Ieno, E. N., Walker, N., Saveliev, A., and Smith, G. (2009). Mixed Effects Models and Extensions in Ecology with R. New York, NY: Springer \& Business Media.

Conflict of Interest: The authors declare that the research was conducted in the absence of any commercial or financial relationships that could be construed as a potential conflict of interest.

Publisher's Note: All claims expressed in this article are solely those of the authors and do not necessarily represent those of their affiliated organizations, or those of the publisher, the editors and the reviewers. Any product that may be evaluated in this article, or claim that may be made by its manufacturer, is not guaranteed or endorsed by the publisher.

Copyright (C) 2022 Stevenson, Ó Corcora, Harley and Baumiller. This is an openaccess article distributed under the terms of the Creative Commons Attribution License (CC BY). The use, distribution or reproduction in other forums is permitted, provided the original author(s) and the copyright owner(s) are credited and that the original publication in this journal is cited, in accordance with accepted academic practice. No use, distribution or reproduction is permitted which does not comply with these terms. 